\title{
A Different Cause of Mimicking Acute Abdominal Findings in the Emergency Department: Ingestion of Codeine and Caffeine Combinations
}

\author{
Acil Serviste Akut Abdomen Bulgularını Taklit Eden Farklı Bir Neden: Kodein ve \\ Kafein Kombinasyonlarının Oral Alımı
}

Șebnem Eren Çevik', Onur Yeșil2, Tuba Cimilli Öztürk2, Özlem Güneysel ${ }^{3}$

'Department of Emergency Medicine, Pașabahce State Hospital, İstanbul, Turkey

${ }^{2}$ Clinic of Emergency Medicine, Ümraniye Training and Research Hospital, İstanbul, Turkey

${ }^{3}$ Clinic of Emergency Medicine, Dr. Lütfi Kırdar Kartal Education and Research Hospital, İstanbul, Turkey

\section{ABSTRACT}

Codeine is a methylmorphine which has a minor role in the ambulatory treatment of pain. Caffeine (1, 3, 7-trimethylxanthine) is a plant alkaloid found in a wide variety of foods and beverages. Nausea, cramping, and constipation are side effects of codeine. Toxic effects of caffeine include vomiting, abdominal pain, cardiovascular effects and central nervous system (CNS) symptoms. A 24 year old male patient was admitted to our Emergency Department with a sudden beginning abdominal pain. It was learned that codeine and caffeine combination tablets containing $275 \mathrm{mg}$ caffeine, 120 mg codeine, 4350 mg paracetamol, 14 mg chlorpheniramine maleate and $450 \mathrm{mg}$ propyphenazone were ingested as a suicide attempt. The physical exam revealed diffuse abdominal tenderness and rebound. Abdominal pain was interpreted as an adverse affect of ingestion of codeine and caffeine combinations. Abdominal pain attacks continuing 2 to 3 hours, followed by painless periods, were recurred. Consecutive leukocyte counts remained in normal ranges. The patient was hospitalized for observation at general surgery ward. Codeine, caffeine combinations both cause abdominal pain as an adverse effect and abdominal findings can be confused with acute abdomen. Therefore the story and the serial abdominal examinations have significant role in diagnosis and management.

Keywords: Codeine, caffeine, abdominal pain, suicide attempt Received: 12.05.2011 Accepted: 13.06.2011

\section{ÖZET}

Kodein ag̃rı tedavisinde az etkinlig̃i olan bir metilmorfindir. Kafein (1, 3, 7-trimetilksantin) ise birçok yiyecek ve içecekte bulunan bitkisel bir alkaloidtir. Kodeinin yan etkileri, bulantı, kramp tarzı ag̃rı ve konstipasyondur. Kafein toksik etkileri ise kusma, abdominal ag̃rı, kardiyovasküler etkiler ve santral sinir sistemi (SSS) semptomlarını içerir. Yirmi dört yașında erkek hasta ani bașlayan karın ag̃rısı şikayeti ile Acil Servis'e bașvurdu. Hastanın intihar amaçI. 275 mg kafein, 120 mg kodein, 4350 mg parasetamol, 14 mg klorfeniramin maleat ve $450 \mathrm{mg}$ propifenazon içeren kodein ve kafein kombinasyonu aldıg̃ı ög̃renildi. Fizik muayenesinde abdominal hassasiyet ve rebound vardı. Abdominal ag̃rı kodein ve kafein kombinasyonlarının yan etkisi olarak yorumlandı. İki-üç saat süren ve ag̃rısız periodların takip ettig̃i abdominal ag̃rı atakları tekrarladı. Seri olarak çalıșılan lökosit sayımları normal deg̃erlerde seyretti. Hastanın gözlemlemek amacıyla genel cerrahi klinig̃ine yatıșı yapıldı. Kodein, kafein kombinasyonlarının her ikisi de yan etki olarak abdominal ag̃rıya neden olur ve abdominal bulgular akut batın ile karışabilir. Bu nedenle tanı ve tedavide öykü ve tekrarlayan abdominal muayenenin önemli bir rolü vardır.

Anahtar Kelimeler: Kodein, kafein, abdominal ag̃rı, intihar girișimi Geliş Tarihi: 12.05.2011 Kabul Tarihi: 13.06.2011 


\section{Introduction}

Codeine and caffeine combinations are drugs frequently used in the symptomatic treatment of upper respiratory tract infections. These drugs are generally sold over the counter and easily attainable.

Codeine is a methylmorphine and it is a weak opioid receptor agonist which has a minor role in the ambulatory treatment of pain $(1,2)$. It is available as a sole ingredient and in combination with aspirin or acetaminophen (1). It also has an antitussive action and can be administered by intravenous or oral route. Caffeine (1, 3, 7-trimethylxanthine) is a plant alkaloid found in a wide variety of foods and beverages. Coffee, tea, and chocolate have a natural concentration of caffeine. Caffeine is also added to carbonated beverages and a large number of over-the-counter medications including weight control aids, alertness tablets, pain relievers, diuretics, and cold remedies. It can be administered by a number of routes, including oral, intravenous, subcutaneous and rectal (3).

Although often prescribed for mild to moderate pain, codeine is a poor choice because of its tendency to cause side effects, especially nausea, cramping, and constipation, at doses that provide limited analgesia (2). On the other hand, average doses of caffeine (85-250 mg, the equivalent of 1-3 cups of coffee) may result in feelings of alertness, decreased fatigue, and easier flow of thought (4). Toxic effects include vomiting, abdominal pain, and central nervous system (CNS) symptoms, including agitation, altered conscious state, rigidity and seizures. The cardiovascular effects include supraventricular and ventricular tachyarrhythmias (5).

In this case report, we aimed to point out abdominal cramping, a rare presentation of intoxications with codeine and caffeine combinations.

\section{Case Report}

A 24 year old male patient was admitted to our Emergency Department with a sudden onset of abdominal pain. It was learned that he had ingested a total of 15 codeine and caffeine combination tablets containing 275 mg caffeine, 120 mg codeine, 4350 mg paracetamol $14 \mathrm{mg}$ chlorpheniramine maleate and $450 \mathrm{mg}$ propyphenazone as a suicide attempt. He was brought to the emergency department 1 hour after ingestion. He was conscious, cooperative and orientated. At the time of arrival his vital signs were as follows; blood pressure 140/80 mmHg, pulse rate 73 beats/min, respiratory rate 18 breaths/ min, axillary temperature $39.1^{\circ} \mathrm{C}$, and oxygen saturation $98 \%$ on room air and Glasgow Coma Score was 15 (E4V5M6). The physical exam revealed diffuse abdominal tenderness and rebound. The other system examinations, electrocardiogram, arterial blood gases and blood tests including hemogram, biochemical, coagulation tests and urinalysis were normal. He was monitored, an orogastric tube was inserted for the aspiration of gastric contents and activated charcoal (1 gr/ kg) was administered via the tube. Abdominal ultrasonography was evaluated as normal. He was referred to a surgeon and abdominal pain was interpreted as an adverse effect of ingestion of codeine and caffeine combinations. He was followed up in the observation room in the Emergency Department. Despite diminished abdominal pain, the recurrent attacks continued for 2 to 3 hours, followed by painless periods. In consecutive blood tests, leukocyte counts remained in normal ranges. However in each field the leukocyte count was 34 in the urinalysis on the second day of admission. Because of the ongoing abdominal pain, the patient was hospitalized for observation in the general surgical ward. Oral intake was stopped and supportive treatment (1000 cc 0.9\% NaCl intravenous infusion) was continued. He was followed up with serial blood tests and repeated abdominal examinations. During the hospitalization period, he was also referred to a psychiatrist. On the second day of hospitalization, oral intake was started; due to diminution in abdominal pain and normal physical examination, the patient was discharged with the stipulation that he was attended follow-up controls.

\section{Discussion}

Codeine and caffeine combinations are usually used in the symptomatic treatment of upper respiratory tract infections or pain management. These are sold over the counter and easily attainable and it is known that both cause gastrointestinal symptoms.

Codeine often causes gastrointestinal cramping and pain. Treatment for such symptoms is usually symptomatic and supportive. It is known that decreased gastrointestinal motility is a common finding with therapeutic use and overdose of opioids. Severe cases may develop ileus. Increased biliary tract pressures and choledochoduodenal sphincter spasm occur with therapeutic dosing of many opioids, including morphine, meperidine, and codeine. Presenting clinical symptoms mimic biliary colic and may respond to naloxone or glucagons (6).

Caffeine has differing CNS, cardiovascular, and metabolic effects based on the quantity ingested. Average doses of caffeine (85-250 mg, the equivalent of 1-3 cups of coffee) may result in feelings of alertness, degreased fatigue, and easier flow of thought (4). Toxic effects of caffeine include vomiting, abdominal pain, and CNS symptoms, including agitation, altered conscious state, rigidity and seizures. The cardiovascular effects include supraventricular and ventricular tachyarrhytmias (5).

Paracetamol ingestion may also cause abdominal pain but this may occur in toxic doses (7). Our patient ingested $4350 \mathrm{mg}$ paracetamol and this is not within toxic ranges. Clorpheniramine is an inhibitor of $\mathrm{H}_{1}$-histamine receptors and it does not cause abdominal pain as an adverse effect (8). Propyphenazone is an anti-inflammatory and anti-pyretic agent. There are a few studies about the adverse effects of propyphenazone, Boerlin et. al. (9) reported that propyphenazone can cause side effects including tiredness, nausea, headache, dizziness, stomachache, lack of concentration, vomiting, feeling of relaxation, warmth and heaviness in 150-300 mg doses. Our patient ingested $450 \mathrm{mg}$ propyphenazone and it can also be the reason for the abdominal pain. Hastier et al., reported four cases of codeine induced pancreatitis, which is one of the diagnoses of abdominal pain. All four had ingested a therapeutic dose of codeine 1-3 $\mathrm{h}$ before the onset of abdominal symptoms and all had had a previous cholecystectomy. The probable underlying pathophysiologi- 
cal mechanism is codeine-induced spasm of the sphincter of Oddi combined with sphincter of Oddi dysfunction related to a previous cholecystectomy. In these cases, serum amylase and lipase were elevated (10). In the history of our patient there was no previous cholecystectomy, the serum amylase was $75 \mathrm{U} / \mathrm{L}$ and the abdominal examination revealed intermittent tenderness and rebound. These findings diminished on the second day of hospitalization.

On the other hand, axillary temperature was $39.1^{\circ} \mathrm{C}$. To our knowledge, one effect of the caffeine and also clorpheniramine toxicity may be fever $(11,12)$.

Because the leukocyte count was 34 in each field in urinalysis on the second day of admission, the other potential cause of fever was urinary system infection.

Codeine, caffeine and propyphenazone have the potential of causing abdominal pain as an adverse effect. In our patient the characteristic of pain was an intermittent, transient abdominal pain which appeared in attacks and caused acute abdomen findings such as diffuse abdominal tenderness and rebound.

\section{Conclusion}

Codeine and caffeine combinations are frequently encountered drugs in suicide attempts. The reason is that these drugs are soldover the counter and easily attainable. It is known that codeine and caffeine combinations cause abdominal pain as an adverse effect and abdominal findings can be confused with acute abdomen. Therefore the history and serial abdominal examinations have a significant role in the diagnosis and management.

\section{Conflict of interest}

No conflict of interest was declared by the authors.

\section{References}

1. Yip L, Garbane BM, Borron SW. Opioids. In: Shannon MW, Borron SW, Burns MJ, eds. Haddad and Winchester's Clinical Management of Poisoning and Drug Overdose. 4th ed. Philadelphia: Saunders, 2007. MD Consult Web site. Available at http://www.mdconsult.com Access date May 2, 2011.

2. Miner JR, Paris PM, Yealy DM. Pain Management. In: Marx JA, Hockberger RS, Walls RM, Adams JG, BarsanWG, Biros MH, et al, eds. Rosen's Emergency Medicine Concepts and Clinical Practice. Vol 2. 7th ed: Saunders, An Imprint of Elsevier Inc.; 2010;p.2410-28.

3. Shannon MW. Theophylline and Caffeine. In: Shannon MW, Borron SW, Burns MJ., eds. Haddad and Winchester's Clinical Management of Poisoning and Drug Overdose. 4th ed. Philadelphia: Saunders, 2007. MD Consult Web site. Available at. Access date May 2, 2011.

4. Yew D, Laczek JT. Toxicity, Caffeine emedicine from WebMD. Nov 5, 2009. http://emedicine.medscape.com. Access date May 2, 2011.

5. Holmgren P, Norden-Pettersson L, Ahlner J. Caffeine Fatalities - Four Case Reports. Forensic Sci Int 2004; 139: 71-3. [CrossRef]

6. Bardsley CH. Opioids. In: Marx JA, Hockberger RS, Walls RM, Adams JG, BarsanWG, Biros MH, et al., eds. Rosen's Emergency Medicine Concepts and Clinical Practice. Vol 2. 7th ed: Saunders, An Imprint of Elsevier Inc.; 2010. p.2047-2051.

7. Hung OL, Nelson LS. Chapter 184. Acetaminophen. In: Tintinalli JE, Stapczynski JS, Cline DM, Ma OJ, Cydulka RK, Meckler GD, eds. Tintinalli's Emergency Medicine: A Comprehensive Study Guide. 7th ed: http:// www.accessmedicine.com. Access date May 2, 2011.

8. Kirk MA, Baer AB. Anticholinergics and Antihistamines. In: Shannon MW, Borron SW, Burns MJ., eds. Haddad and Winchester's Clinical Management of Poisoning and Drug Overdose. 4th ed. Philadelphia: Saunders, 2007. MD Consult Web site. Available at. Access date[ May 2, 2011.

9. Boerlin V, Maeglin B, Hägler W, Kuhn M, Nüesch E. Analgesic Activity of Propyphenazone in Patients With Pain Following Oral Surgery. Eur J Clin Pharmacol 1986; 31: 127-31. [CrossRef]

10. Hastier P, Buckley MJM, Peten EM, Demuth N, Dumas R, Demarquay JF. A New Source of Drug-Induced Acute Pancreatitis: Codeine. Am J Gastroenterol 2000; 95: 3295-8. [CrossRef]

11. Holstege CP. Caffeine. Encyclopedia of Toxicology 2005: 377-9. [CrossRef]

12. Biearman BS. Chlorpheniramine Encyclopedia of Toxicology $2005 ; 577-8$. 